\title{
Oxidant stress in asthma
}

\author{
Ryszard Dworski
}

Asthma is a chronic inflammatory disease of the respiratory tract of unknown aetiology. In severe asthma airway diathesis is profound, and thus apparent. Recently, however, evidence has indicated that specific inflammatory abnormalities exist even in the airways of subjects with mild disease. As inflammation is often associated with an increased generation of reactive oxygen species (ROS), and the biochemical environment in the asthmatic airways is favourable for free radical mediated reactions, it is rational to surmise that an oxidant stress could be mechanistically important in asthma.

\section{Cellular and biochemical sources of ROS in asthma}

The inflammatory cells recruited to the asthmatic airways have an exceptional capability for producing ROS. Activated eosinophils, neutrophils, monocytes, and macrophages can generate superoxide $\left(\mathrm{O}_{2}^{-}\right)$via the membrane associated NADPH-dependent complex. Subsequently, dismutation of $\mathrm{O}_{2}^{-}$gives hydrogen peroxide $\left(\mathrm{H}_{2} \mathrm{O}_{2}\right) \cdot \mathrm{O}_{2}^{-}$and $\mathrm{H}_{2} \mathrm{O}_{2}$ per se are moderate oxidants; however, both species are critical for the formation of potent cytotoxic radicals in biological systems through their interaction with other molecules. For example, hydroxyl radical $\left({ }^{\circ} \mathrm{OH}\right)$, a powerful and indiscriminate oxidant, can be produced from $\mathrm{O}_{2}{ }_{2}^{-}$ and hypohalous acids ( $\mathrm{HOCl}$ or $\mathrm{HOBr}$ ). The latter component can be formed from $\mathrm{H}_{2} \mathrm{O}_{2}$ and a halide $\left(\mathrm{Cl}^{-}\right.$or $\left.\mathrm{Br}^{-}\right)$in a reaction catalysed by myeloperoxidase (MPO) provided by neutrophils and monocytes, ${ }^{1}$ or eosinophil peroxidase (EPO) from eosinophils. ${ }^{2} \mathrm{MPO}$ preferably utilises $\mathrm{Cl}^{-}$as a halide, whereas EPO uniquely prefers $\mathrm{Br}^{-}$. Moreover, a recent study has shown that MPO and EPO can use nitrite (a major end product of nitric oxide (NO) metabolism) and $\mathrm{H}_{2} \mathrm{O}_{2}$ as substrates to promote formation of reactive nitrating intermediates. ${ }^{3}$ The oxidative injury caused by eosinophils can be substantial because the cells possess several times greater capacity to generate $\mathrm{O}_{2}^{-}$and $\mathrm{H}_{2} \mathrm{O}_{2}$ than neutrophils, ${ }^{4}$ and the content of EPO in eosinophils is $2-4$ times higher than the amount of MPO in neutrophils. ${ }^{5}$ Another example of a powerful oxidant and a nitrating radical is peroxynitrite $\left(\mathrm{ONOO}^{-}\right)$produced from the reaction of $\mathrm{O}_{2}{ }^{-}$ with $\mathrm{NO}^{6}$ This pathway may be involved in asthma because the concentration of $\mathrm{NO}$ is increased in the asthmatic airways. ${ }^{7}$ In addition to the recruited inflammatory cells, the constitutive airway cells such as epithelial cells are also potential sources of ROS. ${ }^{8}$ Moreover, cells recovered from bronchoalveolar lavage (BAL) fluid and blood of asthmatic subjects have been shown to generate greater amounts of ROS at baseline and after stimulation ex vivo than in normal subjects, a feature which in some studies correlated with disease severity. This suggests that the biochemical milieu in asthma contains factors which prime oxidative pathways in vivo. ${ }^{9-14}$

As in many other pathological conditions, the oxidant "burst" in asthma is presumably a self propagating non-specific process initiated by the concurrent action of numerous inflammatory pathways. Several asthma mediators including lipid mediators, ${ }^{15}$ chemokines, ${ }^{16}{ }^{17}$ adhesion molecules, ${ }^{18}$ and eosinophil granule proteins ${ }^{19}$ are potential stimuli or promoters of ROS production. In addition to endogenous sources, some environmental factors linked to asthma such as air pollutants (for example, ozone, diesel exhaust particles) may cause an extreme increase of ROS generation in the airways. ${ }^{20}$

In principle an increase in the production of ROS is problematic because oxidation of proteins, DNA, and lipids may cause direct tissue injury or evoke a variety of cellular responses through the generation of secondary reactive species. ${ }^{21}$

\section{Antioxidants and asthma}

Numerous disturbances of antioxidant defence mechanisms have been described in asthma. For example, the expression of the asthma phenotype has been linked to reduced selenium status, an essential element for the normal activity of glutathione peroxidase, ${ }^{22} 23$ and insufficient dietary intake of vitamins with antioxidant properties, particularly in smokers. ${ }^{24-26}$ Decreased activity of copper and zinc containing superoxide dismutase $(\mathrm{Cu}, \mathrm{Zn}$ SOD) in bronchial epithelial cells and BAL fluid cells has recently been found in asthmatic subjects not using inhaled corticosteroids compared with corticosteroid treated asthmatic patients and normal subjects. This was caused by an altered expression of the enzyme, which was similar in all groups. Treatment with inhaled corticosteroids abolished the abnormality. No difference in the activity of manganese containing SOD (Mn-SOD), catalase, and glutathione peroxidase was detected between asthmatic and control subjects. The activity of SOD correlated with non-specific airway reactivity assessed by methacholine challenge. ${ }^{27}{ }^{28} \mathrm{~A}$ polymorphism in antioxidant enzymes-for example, Mn-SOD and glutathione S-transferase- has also been reported in asthmatic subjects. ${ }^{29}$ Nevertheless, the significance of these abnormalities in the pathogenesis of asthma is unclear at this time. 
Could increased activity of ROS have a role in the pathogenesis of asthma?

The exposure of animals in vivo and human airway tissue in vitro to different oxidants has been shown to produce airway constriction and hyperresponsiveness. ${ }^{30-32}$ However, the relevance of these experiments to human asthma is uncertain. Of interest, however, are recent studies suggesting that ROS mediated reactions may alter or induce some inflammatory and immunological cellular responses-for example, through the generation of second messengers. It is important to emphasise that the consequences of oxidant stress may vary in normal lungs and in lungs with pre-existing allergic inflammation caused by a different biochemical and cellular environment. Nevertheless, some of the effects mediated by ROS with a feasible role in asthmatic inflammation and airway remodelling include activation of transcription factors such as STATs and $\mathrm{NF}-\kappa \mathrm{B},{ }^{33-35}$ modulation of glucocorticoid dependent signal transduction, ${ }^{36}$ stimulation of phospholipase and eicosanoid synthesis, ${ }^{37-39}$ induction of growth factors, ${ }^{40}$ cytokines, ${ }^{41}$ and modification of cellular ion transport mechanisms. ${ }^{42}$ Specific studies will be necessary to establish which of these effects could be involved in asthma.

Evidence for oxidative stress in asthma Much of the evidence for the activity of ROS in asthma is indirect or circumstantial because there are no reliable methods to assess oxidative stress in vivo. Thus, the measurement of increases in $\mathrm{NO}, \mathrm{H}_{2} \mathrm{O}_{2}$, and pentane in exhaled gas or breath condensates, analysis of lipid peroxidation based on diene conjugate and thiobarbituric acid (TBA), and the assessment of substrate oxidisability (or spin trapping) of free radical adducts ex vivo all have low sensitivity and specificity. However, using these procedures, an augmented production of ROS has been found in adults and children with distinct asthma severity and acute exacerbations of asthma. ${ }^{12}$ 43-48 The specific measurement of $\mathrm{F}_{2}$-isoprostanes ( $\mathrm{F}_{2}$-IsoPs), stable prostaglandin-like arachidonate products formed on membrane phospholipids by the action of ROS, has recently been found to be a sensitive and reliable non-invasive method for assessing oxidant stress in vivo. Indeed, $\mathrm{F}_{2}-$ IsoPs are increased in a number of human vascular and inflammatory disorders in which oxidant stress has been thought to play a significant role. ${ }^{49}$ Using a sensitive and specific mass spectrometry method we found increased concentrations of urinary $\mathrm{F}_{2}$-IsoPs in patients with atopic asthma following inhaled allergen challenge. The formation of $\mathrm{F}_{2}$-IsoPs was a specific response to allergen because the non-specific bronchoconstrictor methacholine did not cause an increase in $\mathrm{F}_{2}$-IsoPs. The measured compounds were noncyclooxygenase products because they were not abrogated by pretreatment of the subjects with adequate doses of either aspirin or indomethacin. $\mathrm{F}_{2}$-IsoPs were also increased in the BAL fluid 24 hours after segmental instillation of the allergen and the increase was inhib- ited by pretreatment with inhaled corticosteroids, which suggests that steroids may act in part by restraining oxidant stress. Thus, this study provided direct evidence that oxidant injury occurs in allergic inflammation..$^{50}$ This conclusion was further validated by showing that inhaled allergen challenge caused enhanced excretion of 2,3-dinor-5,6-dihydro-15$\mathrm{F}_{2 \mathrm{t}}$-IsoP $\left(\mathrm{F}_{2 \mathrm{t}}\right.$-IsoP-M), the major urinary metabolite of $15-\mathrm{F}_{2 \mathrm{t}}$-IsoP $\left(8\right.$-iso- $\left.\mathrm{PGF}_{2 \alpha}\right)$. $^{51}$ Measurement of a metabolite of $\mathrm{F}_{2}$-IsoPs provides a more reliable index of total systemic production of IsoPs because, unlike unmetabolised $\mathrm{F}_{2}$-IsoPs, the metabolite cannot be produced in the kidney nor be generated artefactually by auto-oxidation of arachidonic acid during sample handling and storage (Dworski et al. unpublished data). We have also found increased release of $\mathrm{F}_{2}$-IsoPs and $\mathrm{F}_{2 \mathrm{r}}$-IsoP-M into the urine of patients with aspirin induced asthma following challenge with inhaled lysineaspirin (Dworski et al., unpublished observation).

If ROS are important in asthma, enhancement of the antioxidant defences would be expected to have beneficial effects in the disease. In this regard the available data in humans are unimpressive. Unfortunately, one of the major weaknesses of the studies to date is the lack of evidence that the chosen doses and mixtures of antioxidants were effective in vivo. ${ }^{52}{ }^{53}$ We anticipate that measurement of the urinary excretion of $\mathrm{F}_{2}$-IsoP-M may provide a novel method to define the most effective dosages and combinations of antioxidants to suppress oxidant stress in patients with asthma, which will permit a reliable assessment of the effect of antioxidant treatment on the pathophysiology of the disease process.

\section{Conclusion}

There is evidence that oxidant stress occurs in asthma, which is not surprising considering the inflammatory nature of the disease. However, little is known about the role of ROS in the inflammatory and immunological cascade characteristic of asthma. This is a provocative question because some of the mechanisms may bypass the therapeutic effects of antiinflammatory drugs, and antioxidant agents could prove useful adjuvant treatment for asthma.

This work was supported by NIH grant GM15431. The author This work was supported by NIH grant GM15431. The author
thanks Tamara Lasakow for editorial assistance in preparing the thanks Tama
manuscript. for myeloperoxidase-dependent hydroxyl radical formation by human neutrophils and monocytes. If Biol Chem 1992;267:8307-12.

2 McCormick ML, Roeder TL, Railsback MA, et al. Eosinophil peroxidase-dependent hydroxyl radical generation by human eosinophils. F Biol Chem 1994;269:27914-9.

3 Wu W, Chen Y, Hazen SL. Eosinophil peroxidase nitrates protein tyrosyl residues. F Biol Chem 1999;274:25933-44.

4 Slungaard A, Vercellotti GM, Walker G, et al. Tumor necrosis factor alpha/cachectin stimulates eosinophil oxidant production and toxicity towards human endothelium. $\mathcal{F}$ Exp Med 1990;171:2025-41.

5 Bozeman PM, Learn DB, Thomas EL. Assay of the human leukocyte enzymes myeloperoxidase and eosinophil peroxidase. F Immunol Methods 1990;126:125-33.

6 Pryor WA, Squadrito G. The chemistry of peoxynitrite: a

Pryor WA, Squadrito G. The chemistry of peoxynitrite: a
product from the reaction of nitric oxide with superoxide. product from the reaction of nitric
Am $\mathcal{F}$ Physiol 1995;268:L669-722. 
7 Kharitonov SA, Yates D, Robbins RA, et al. Increased nitric oxide in exhaled air of asthmatic patients. Lancet 1994;343. oxide in

8 Rochelle LG, Fischer BM, Adler KB. Concurrent production of reactive oxygen and nitrogen species by airway epithelial cells in vitro. Free Radic Biol Med 1998;24:863-8.

9 Cluzel M, Damon M, Chanez P, et al. Enhanced alveolar cell luminol-dependent chemiluminescence in asthma. $\mathscr{f} \mathrm{Al}$ lergy Clin Immunol 1987;80:195-201.

10 Sedgwick JB, Geiger KM, Busse WW. Superoxide generation by hypodense eosinophils from patients with asthma Am Rev Respir Dis 1990;142:120-5.

11 Kanazawa H, Kurihara N, Hirata $\mathrm{K}$, et al. The role of free radicals in airway obstruction in asthmatic patients. Chest 1991;100:1319-22.

12 Calhoun WJ, Reed HE, Moest DR, et al. Enhanced superoxide production by alveolar macrophages and
air-space cells, airway inflammation, and alveolar macroair-space cells, airway inflammation, and alveolar macro-
phage density changes after segmental antigen bronchoprovocation in allergic subjects. Am Rev Respir Dis provocation in

13 Vachier I, Damon M, Le Doucen C, et al. Increased oxygen species generation in blood monocytes of asthmatic

14 Sanders SP, Zweier JL, Harrison SJ, et al. Spontaneous oxygen radical production at sites of antigen challenge in aller-
gic subjects. Am $\mathcal{A}$ Respir Crit Care Med 1995;151:1725-33. gic subjects. Am ₹ Respir Crit Care Med 1995;151:1725-33.

5 Bruijnzeel PL, Koenderman L, Kok PTM, et al. Platelet activating factor (PAF-acether) induced leukotriene $\mathrm{C}_{4}$ formation and luminol dependent chemiluminescence of human eosinophils. Pharm Res Comm 1986;18:61-9.

16 Chihara J, Hayashi N, Kakazu T, et al. RANTES augments radical oxygen products from eosinophils. Int Arch Allergy Immunol 1996;104(Suppl):52-3.

17 Tenscher K, Metzner B, Schopf E, et al. Recombinant human eotaxin induces oxygen radical production, $\mathrm{Ca}(2+)$-mobilization, actin reorganization, and CD $11 \mathrm{~b}$ upregulation in human eosinophils via a pertussis toxinsensitive heterotrimeric guanine nucleotide-binding prosensitive heterotrimeric guani
tein. Blood 1996;88:3195-9.

18 Nagata M, Sedgwick JB, Vrtis R, et al. Endothelial cells upregulate eosinophil superoxide generation via VCAM-1 expression. Clin Exp Allergy 1998:29:550-61.

19 Rankin JA, Harris P, Ackerman SJ. The effect of eosinophilgranule major basic protein on lung-macrophage superoxide anion generation. F Allergy Clin Immunol 1992;89:74652.

20 Bascom R, Bromberg PA, Costa DA, et al. Health effects of outdoor air pollution. Part I. State of the art. Am f Respi Crit Care Med 1996;153:3-50.

21 Halliwell B. Reactive oxygen species in living systems: source, biochemistry, and role in human disease. $A m \mathcal{F} M e d$ 1991;91:14-22S

22 Flatt A, Pearce N, Thomson CD, et al. Reduced selenium in asthmatic subjects in New Zealand. Thorax 1990;45:95-9.

23 Misso NLA, Powers KA, Gillon RL, et al. Reduced platelet glutathione peroxidase activity and serum selenium concentration in atopic asthmatic patients. Clin Exp Allergy centration in atopic

24 Soutar A, Seaton A, Brown K. Bronchial reactivity and dietary antioxidants. Thorax 1

25 Bodner C, Godden D, Brown K, et al. Antioxidant intake and adult-onset wheeze: a case-control study. Eur Respir $\mathcal{F}$ 1999;13:22-30

26 Baker JC, Tunnicliffe WS, Duncanson RC, et al. Dietary antioxidants and magnesium in type 1 brittle asthma: a case control study. Thorax 1999;54:115-8.

27 De Raeve HR, Thunnissen FBJM, Kaneko FT, et al. Decreased $\mathrm{Cu}, \mathrm{Zn}-\mathrm{SOD}$ activity in asthmatic airway epithelium: correction by inhaled corticosteroids in vivo. Am f Physiol 1997;272:L148-54.

28 Smith LJ, Shamsuddin M, Sporn PHS, et al. Reduced superoxide dismutase in lung cells of patients with asthma. Free Radic Biol Med 1997;22:1301-7.

29 Hepple M, Fryer AA, Alldersea J, et al. Susceptibility in bronchial asthma: influence of genes that protect against bronchial asthma: influence of genes that protect against

30 Hulsmann AR, Raatgeep HR, Den Hollander JC, et al. Oxidative epithelial damage produces hyperresponsiveness of
human peripheral airways. Am $\mathcal{7}$ Respir Crit Care Med 1994;149:519-25.
31 Sadeghi-Hashjin G, Folkerts G, Henricks PAJ, et al. Peroxynitrite induces airway hyperresponsiveness in guinea pigs in vitro and in vivo. Am $\mathcal{J}$ Respir Crit Care Med 1996:153:1697-701.

32 Cortijo J, Martí-Cabrera M, De La Asunción JG, et al. Conraction of human airways by oxidative stress protection by $\mathrm{N}$-acetylcysteine. Free Radic Biol Med 1999;27:392-400.

33 Schreck R, Rieber P, Baeuerle PA. Reactive oxygen intermediates as apparently widely used messengers in the activation of the NF- $\mathrm{kB}$ transcription factor and HIV-1. EMBO ₹ 1991; 10:2247-58.

34 Simon AR, Rai U, Fanburg BL, et al. Activation of the JAKSTAT pathway by reactive oxygen species. Am $\mathcal{f}$ Physiol 1998:275:C1640-52.

35 Uchida K, Shiraishi M, Naito Y, et al. Activation of stress signaling pathways by the end product of lipid peroxidation. $\mathcal{F}$ Biol Chem 1999;274:2234-42.

36 Okamoto K, Tanaka H, Ogawa H, et al. Redox-dependent regulation of nuclear import of the glucocorticoid receptor. f Biol Chem 1999;274:10363-71.

37 Rashba-Step J, Tatoyan A, Duncan R, et al. Phospholipid peroxidation induces cytosolic phospholipase $\mathrm{A}_{2}$ activity: membrane effects versus enzyme phosphorylation. Arch Biochem Biophys 1997;343:44-54.

38 Feng L, XIA Y, Garcia GE, et al. Involvement of reactive oxygen intermediates in cyclooxygenase- 2 expression induced by interleukin- 1 , tumor necrosis factor- $\alpha$, and lipopolysaccharide. F. Clin Invest 1995;95:1669-75.

39 Landino LM, Crews BC, Timmons MD, et al. Peroxynitrite, the coupling product of nitric oxide and superoxide, activates prostaglandin biosynthesis. Proc Natl Acad Sci USA 1996:93:15069-74.

40 Leonarduzzi G, Scavazza A, Biasi F, et al. The lipid peroxidation end product 4-hydroxy-2,3-nonenal up-regulates transforming growth factor bl expression in the macrophage lineage: a link between oxidative injury and fibrosclerosis. FASEB F 1997;11:851-7.

41 DeForge LE, Preston AM, Takeuchi, et al. Regulation of interleukin 8 gene expression by oxidant stress. 7 Biol Chem 1993;268:25568-76.

42 Kourie JI. Interaction of reactive oxygen species with ion transport mechanisms. Am $\mathcal{F}$ Physiol 1998;275:C1-24.

43 Owen S, Pearson D, O'Driscoll R. Evidence of free-radical activity in asthma. N Engl f Med 1991;325:586-7.

44 Dohlman AW, Black HR, Royall JA. Expired breath hydrogen peroxide is a marker of acute airway inflammation in pediatric patients with asthma. Am Rev Respir Dis 1993;148:955-60

45 Antczak A, Nowak D, Shariati B, et al. Increased hydrogen peroxide and thiobarbituric acid-reactive products in expired breath condensate of asthmatic patients. Eur Respir f 1997; 10:1235-41.

46 Olopade CO, Zakkar M, Swedler WI, et al. Exhaled pentane evels in acute asthma. Chest 1997;111:862-5.

47 Saleh D, Ernst P, Lim S, et al. Increased formation of the potent oxidant peroxynitrite in the airways of asthmatic patients is associated with induction of nitric oxide synthase: effect of inhaled glucocorticoid. FASEB $f$ 1998:12:929-37.

48 Jarjour NN, Busse WW, Calhoun WJ. Enhanced production of oxygen radicals in nocturnal asthma. Am Rev Respir Dis 1992:146:905-11.

49 Morrow JD, Roberts LJ II. The isoprostanes: unique bioactive products of lipid peroxidation. Prog Lipid Res 1997;36: $1-21$

50 Dworski R, Murray JJ, Roberts LJ II, et al. Allergen-induced synthesis of F2-isoprostanes in atopic asthmatics:evidence or oxidant stress. Am F Respir Crit Care Med 1999;160: 1947-51.

51 Morrow JD, Zackert WE, Yang JP, et al. Quatification of the major urinary metabolite of $15-\mathrm{F}_{2 \alpha}$-isoprostane (8-iso$\mathrm{PGF}_{20}$ ) by a stable isotope dilution mass spectrometric assay. Anal Biochem 1999;269:326-31.

52 Troisi RJ, Willett WC, Weiss ST, et al. A prospective study of diet and adult-onset asthma. Am $\mathcal{F}$ Respir Crit Care Med 1995;151:1401-8.

53 Grievink L, Smit HA, Ocké MC, et al. Dietary intake of monary function: the MORGEN study. Thorax 1998;53: monary 